\title{
7. RITES, WHITES AND MIGHT: A CRITIQUE OF THE EFFECT OF THE REVIVAL OF CUSTOMARY LAW UPON THE AUTONOMY OF INDIGENOUS WOMEN
}

By: Susan Bothmann

\section{KEY TERMS AND PHRASES}

\section{Aboriginal}

Generally of people, animals or plants existing in a place from the earliest time or from before the arrival of colonists. The initial inhabitants of Australia were once most commonly called Aborigines but this term has been replaced more recently by the term Aboriginal(s).

\section{Assimilation}

To absorb and integrate people, ideas or cultures into a wider or more dominant society or culture. To remove the differences exhibited by one nation or group by having it swallowed up into the mainstream. This concept was a deliberate policy of white politicians in Australia for a time, in order to get the Aboriginal population to disappear.

\section{Critique}

A detailed analysis and assessment of something, especially a literary, philosophical, artistic or political theory. The process of discussing critically.

\section{Essentialism}

A view that things have a certain set of characteristics, or an essence, that makes them what they are. In the context of categories of people, the idea that there exist defining characteristics that make, for example, all women, women; or all Aboriginals, Aboriginals and that members of those groups always contain those characteristics.

\section{Exponential}

Originally a mathematical term. Describes the expansion of a thing at a rate where each item increases the capacity for further increases (like population growth). Used generally to describe ever faster growth.

\section{Governance}

The actions taken by a governing body or the manner in which a government governs. 


\section{Indigenous}

Originating or occurring naturally in a particular place. Native. Describes plants, animals and groups of people that are known to hail from a specific area before any other similar stock could have been introduced there.

\section{Lores}

A body of traditions and knowledge held by some particular group. Typically passed from person to person by word of mouth. Often used to describe the rules governing the behaviour of indigenous peoples to contrast them from western style laws.

Mores (Pronouced mor-ays).

The essential or characteristic customs or conventions exhibited by a social group. Acceptable habits and modes of behaviour particularly identifying a specific group of people. Always expressed as a plural noun.

\section{Patriarchal}

A patriarch is the male head of a family or tribe. A patriarchal situation is any situation where men dominate or have power by virtue of being male.

\section{Postmodernism}

A late 20th century style and concept originating in the visual arts and extending into criticism and philosophical debate. It represents a departure from the ideas of modernism. It consists of a general distrust of grand theories and ideologies. Postmodernists try to break down concepts into smaller bits or peel back the layers of notions inherent in any one notion to highlight the invalidity of general overarching claims or ideas.

\section{Poststructuralism}

An extension and critique of structuralism. (Structuralism is the idea that a thing's structure is more important than what it is used for, its function.) Both structuralism and its aftermath are largely French approaches to interpreting language. Jacques Derrida is the most well known exponent. He started writing in the 1960's about deconstructing ideas. His ideas were developed further by departing from structuralism's idea of objectivity. Poststructuralism argues that all things have pluralities and deferred meanings. 


\section{INTRODUCTION}

I always say that I'm Aboriginal first... Then I'm a mother, daughter, sister, aunt, cousin, woman, historian, etc. ${ }^{1}$

I find it difficult to say I'm black first and a woman second or vice versa. I can't make that kind of distinction. ${ }^{2}$

Why should these two Australian Aboriginal women be confronted by an apparent identity conflict? The first question, I suggest, is not how they choose between these hierarchical notions of self, but why they should feel an inclination to do so at all.

This notion of dissecting oneself and parcelling pieces of one's identity up into special categories is a practice that comes from western models of thought and theory ${ }^{3}$ and has had no place in some other social constructs, including the traditional backgrounds from which these two women come. Many traditional indigenous communities do not share western conceptualisations of themselves or their societies. Rather, life is an holistic and integrated experience. This different approach to living has been recognised by western outsiders and sometimes idealised, ${ }^{4}$ sometimes derided.

Customary social structures, customary law, and pre-colonial behavioural norms continue to exert influence upon the lives of most indigenous communities to some extent, both practically and theoretically. Now some indigenous communities are seeking to renew their customary ideas and practices as an overt political project.

In examining the concept of Custom ${ }^{5}$ one must ask whether a return to a customary legal system (which may resolve the quest for identity) will be helpful in achieving political autonomy ${ }^{6}$ for indigenous women of colour. Or may Custom become a vehicle for indigenous men to further disempower and oppress indigenous women?

Adopting customary law as part of the legal system applicable to indigenous people in post-colonial circumstances may increase the oppression experienced by indigenous women unless those women are awake to the structures and interpretations that are placed on Custom by men, indigenous and non-indigenous.

In analysing whether indigenous women's quest for cultural identity is theoretically inconsistent with a desire for autonomy (where such identity is based upon a return to traditional social and legal mores) it will be assumed that indigenous women want both a special identity and autonomy for themselves.

"One cannot claim to be either impartial or comprehensive, nor can one claim to speak for everyone, to everyone, nor about everything." Speaking from the position of 'outsider' one can hope nevertheless to be seen as a sympathetic outsider with some claims to insight into the dilemma faced by the women in the particular communities referred to here. 


\section{POSITIONING FEMINIST DISCOURSE IN THE DEBATE ABOUT CUSTOM}

Recent developments in jurisprudence have been rapid, exponential and diverse. Critical Legal Studies (CLS), Feminist Legal Theor(ies) and Critical Race Theory (CRT) have been launched, extended, inter-related and critiqued. Postmodernism has infiltrated legal philosophy. Generally these discourses have tended to focus on western style legal systems.

The political implications of feminism have been widely explored, for example:

Feminism challenges the construction of knowledge about ourselves and the Other, and is not confined to the critique of a particular discipline. It is also an engaged political project - it seeks knowledge in order to change the 'condition of women'?

Feminist legal scholarship has burgeoned in the past two decades. The most recent developments in feminist legal theory have tended towards "fragmentation, individuation and uncertainty":

This postmodernist approach challenges the notion that women can be encapsulated within some single theory of society and law; denies that the interests of all women are the same, as if there is some 'essential women' (sic) imbued with the characteristics and needs of every woman, irrespective of age, race or class. ${ }^{10}$

Women of colour have played a vital role in highlighting the limitations of thinking about 'woman' as 'essential'. ${ }^{11}$ Non-white female scholars and commentators have berated white feminists for contributing to the plight of women of colour. ${ }^{12}$ They argue that throughout any colonial period of interaction between white western colonisers and indigenous populations, white women have participated actively in the oppression of the coloured minority, including and often, in particular, its women.

White women, whilst undoubtedly victims of oppression themselves, are clearly not innocent victims free from implication in the dominating and controlling of women of colour. ${ }^{13}$ Women of colour argue that today's white middle class feminists cannot appreciate the needs of, cannot represent and cannot incorporate the struggle of nonwhite women. ${ }^{14}$

Some women of colour recognise a 'collective otherness' based on being non-white but they also insist that their particular circumstances set them apart from each other as well. ${ }^{15}$ Some women of colour who feel marginalised or excluded from mainstream feminism identify one version of difference. ${ }^{16}$ Their emphasis on difference is to deny essentialism. Their scholarship highlights their personal experiences. Racism is as great or greater a form of oppression against them, participated in by white women, than sexism. Because this is the reality they experience, they know they must consider the practical and theoretical implications of supporting the views of and seeking solidarity with their own menfolk against whites of both sexes. ${ }^{17}$ Such theoretical considerations also link difference with identity. 
It has become very important for 'post-colonial' indigenous communities to regain their traditions and customs. Indigenous people themselves perceive this return to their own ways as a casting off of the western imposed yoke. It becomes a way of reestablishing their particular identity in the world. A global movement towards recognising and incorporating elements of customary legal systems into 'mainstream' systems in countries that have indigenous populations has emerged. This trend is evident in Australia particularly in relation to Aboriginal land claims ${ }^{18}$ and is manifest in Vanuatu where it has been specifically provided for in the Constitution. ${ }^{19}$

'Difference' is also a theoretical construct behind the desire to return to or renew customary systems. Western democratic, capitalistic legal systems are held to be inappropriate to indigenous populations who crave a social system based on norms which accord with their cultural aspirations. They seek self-determination or the right to be different. This issue of the role, if any, for traditional lores in women's lives is a current concern for indigenous women. It has been raised in relation to Australian Aboriginal women ${ }^{20}$ Canadian first nation peoples, American native peoples ${ }^{21}$ and peoples of the Pacific. ${ }^{22}$

An extensive body of knowledge has accumulated to establish what customary rules really are. ${ }^{23}$ There continues to be controversy about the fact that general knowledge of particular customs is often based on evidence gathered by white anthropologists about certain indigenous rites and social regulations. Beyond the elements of any one customary system the general or non-specific idea of Custom is a fluid concept. In some places there remains a lively and vital tradition. In other places it has been absorbed and must be actively reconstructed by indigenous people. The trend towards a revival of Custom has raised two issues directly important to women.

First, it is perceived by some that traditional mechanisms of social control may be more oppressive towards the women in those societies and more limiting of women's scope for equal rights and humane treatment than a western human rights perspective. ${ }^{24}$ This can be seen, for example, in those countries where there has been a (re)turning to fundamentalism..$^{25}$ 'Oppression' itself is a complex concept:

Actually a family of concepts, oppression has five aspects... exploitation, marginalisation, powerlessness, cultural imperialism, and violence. ${ }^{26}$

From the perspective of indigenous women of colour, while they may endorse the reaffirmation of traditional and cultural mores as a way of asserting their own cultural or racial identity within the larger social environment, they are mindful that this approach can be a means of reducing or taking away some of their hard won 'rights'. It can also create an environment in which the struggle for further rights is made more difficult. ${ }^{27}$ Consider, for example, a ni-Vanuatu woman trying to reconcile her individual right to cast a secret ballot in general elections with her husband's expectation that she will vote as he directs.

Secondly, there has emerged a body of scholarship driven by indigenous women themselves which posits the notion that Custom has been 'bastardised' by exposure to white western legal theories and it is now impossible or dangerous to revert to 
those systems. This thinking starts from the premise that interaction between the indigenous population and the colonial force has been conducted within a framework of western patriarchal power. Even at its most friendly, interest shown in indigenous ways has been by men about 'men's business'. ${ }^{28}$ Where in traditional cultures there was or is a parallel, respected and 'equal' stream of 'women's business' this has been given no attention and has been overshadowed. ${ }^{29}$

Implementation of a political theory encompassing a revival of customary lores could therefore have the negative effect of doubly oppressing indigenous women because indigenous men may take advantage of the imbalance created by an exclusively male perspective that already taints Custom. Indigenous women were indisputably oppressed during colonialism, now they face the prospect of further oppression by having any traditional autonomy reduced. Further, indigenous men may use Custom as a vehicle to shame women into submission by suggesting that any opposition to Custom would be a disloyalty to the collective identity. ${ }^{30}$

Postmodern/poststructural feminists and race/ethnicity feminists recognise that there are diverse forms of power and identity. They share hostility to the ideas of a singular conception of power, and of women as a group. The former deconstruct universalising "procedures in modes of thought" ${ }^{31}$ by showing that these procedures are not neutral but are connected with dominance. In other words, they break down or unpack the elements that lie behind universal concepts and show that in fact they are loaded with value laden assumptions. Those unstated assumptions can allow notions of domination to be continued, implicitly. By contrast, race/ethnicity feminists typically interpret diversity in relation to power and identity in a more cautious way. ${ }^{32}$ They note that supposedly recognised differences between ethnic groups are often perceived as different because of different power positions between the observer and the observed.

It is possible to engage in a deconstruction of the notion of Custom (to show that it is not a neutral concept) without threatening the utility of any customary system as a political vehicle and without denying the fundamental importance of Custom as a sign or indication of identity.

The indigenous women at the Fourth World Conference of Women, held in Beijing, argued for a global strategy that the women's movement struggle be in terms of selfdetermination, rather than gender equality. This is because self-determination is an inclusive concept, incorporating women's right to determine their political status, and economic and social development. ${ }^{33}$ This quest by indigenous women for selfdetermination in the context of gender may have arisen as an ideological offshoot from the postcolonial movements by indigenous peoples to establish their rights to reassert their cultural identities. ${ }^{34}$

Invariably, indigenous people have experienced and are experiencing cultural schizophrenia as a result of colonialisation. That is not to say the experience of every indigenous person is the same but there is no indigenous community that has not been put upon to some extent by another culture. One solution adopted to overcome 
this psychological and political dislocation has been for indigenous communities of colour to look to reaffirming their own cultural mores and re-establishing personal and collective identities from within the refreshed elements of their unique cultures.

It is hard to walk the lines between the two cultures... We do not want to adopt the whiteness of the dominant culture. We want to preserve our brownness... We are happy to be who we are and we are fighting to protect that identity... to allow our culture to continue to live..$^{35}$

The political framework for this quest for indigenous identity arises in part as a reaction to broad based policies of assimilation practised in many places until fairly recently, including Australia and Canada. These policies and practices are perceived by the victims of this approach as a nearly effective form of genocide. Women of colour have also argued that, in theoretical terms, white feminist essentialising of women is another aspect of an assimilationist approach.

Indigenous women of colour acknowledge that they experience being outsiders in relation to their own communities as a product of their gender but they focus more on describing the overwhelming experience and greater sense of 'outsiderhood' in the context of their race and colonised status. Yet the 'corrosive psychic effects' ${ }^{36}$ of discrimination as a form of 'spirit murder" ${ }^{37}$ is not something that every woman experiences in the same way. For indigenous women seeking their own identities through Custom that process itself can constitute further spirit murder if they find their own spiritual needs being denied. Since the role of Custom is theoretically relevant only as it applies within its own community, the element of otherness arises in a purely gender context. In other words, women can feel excluded from the source of their spiritual heritage by being rendered 'outsiders' in their own world solely because of their gender.

\section{WHAT IS CUSTOM? SOME MODELS CONSIDERED}

True 'tribal law' is probably dead everywhere. ${ }^{38}$

$[\mathrm{H}]$ uman communities are living beings that continue to change; while there may be a concept of the 'traditional Indian'... no such being has ever existed. All along there have been changes. ${ }^{39}$

The western model or paradigm of distinguishing our 'legal system' from other spheres of human activity and defining 'laws' specifically as rules for correct behaviour has little place in those social constructs described (from the perspective of the western paradigm) as customary legal systems. Whilst indigenous peoples invariably have (or in some cases, had) modes for organising social governance, these 'systems' might differ widely in content. It is nevertheless possible to identify some common features.

Traditional societies have no culture of individual rights. They maintain their structure and coherence through a culture of duties. ${ }^{40}$ 
No thorough or systematic study of customs and traditions in Melanesia ${ }^{41}$ has been carried out but it is clear that throughout the area "law is not quantifiable as an autonomous institution, but is an aspect of the total way of life of the people". ${ }^{42}$ In the Vanuatu island communities, for example, there is no traditional body of laws that is only understood and applied by specific operatives with special knowledge, such as judges, lawmakers or specifically trained chiefs. There is social order, discipline and control, and many of the languages ${ }^{43}$ include terms that recognise the concepts of codes of conduct, ethics and values, but not the 'rule of law'. ${ }^{4}$

In Melanesian communities there is no 'law' as a definable, isolated concept, but there is a way of life combining the present with the future. The nearest term to describe the concept is the expression pasin ${ }^{45}$ a pidgin rendering of 'fashion'. The notion of law must include "the ways of the people in their total environment, both physical and metaphysical, tangible and intangible, concrete and abstract". ${ }^{46}$

Similarly, when Australian Aboriginal Hobbles Danayarri says " $[\mathrm{m}] \mathrm{y}$ law only one" he is referring to the concept of the Dreaming which is a set of principles governing all human behaviour and indeed the laws of the universe. ${ }^{48}$

A recurring feature of indigenous cultures is a heavy emphasis on the relationship between the community and the land and some form of collective responsibility towards land. ${ }^{49}$ These concepts clearly pre-date any contact with the later colonising powers.

The Australian Aboriginal people have suffered a 200-year period of oppression at the hands of the colonisers and during that time have had their own traditions badly damaged, and in many cases wholly destroyed. This has not been a uniform process. Some communities of people, now described as 'urban aborigines', have been completely dispossessed from their lands and the framework of their cultures by forced separations from their families and by numerous other means. ${ }^{50}$ Other groups, sometimes geographically distinguished as those still living in the desert areas and the 'outback', have retained substantial elements of their older lifestyles and belief systems. These people have struggled to maintain their identities as members of their Aboriginal communities.

The Melanesian experience in Vanuatu is unique. The colonisers there were French and English planters and pastoralists, Catholic and Protestant missionaries, government administrators from both colonising powers and stray 'rascals' who came in numbers to exploit first the whales, then the sandalwood ${ }^{51}$ and other prized timbers, and finally the human economic resource. Hundreds of men were stolen away or 'blackbirded' to work virtually as slaves in Queensland cane fields. ${ }^{52}$

In both places the litany of introduced diseases, rape and pillage, Christianisation and the removal of people to missions, development of farms, stations and plantations and outright murder of the local populations has been the legacy of colonisation for the indigenous communities. It is only fairly recently that the colonisers and others in the west have come to understand the extent of the damage inflicted and the continued struggle by the local people to retain their heritage. The process of cultural 
disintegration was not a simple, straightforward one. Some Aboriginal men 'joined' the outback stations as stockmen whilst others did not. Some Melanesian men and women went to Queensland more than once and some never returned home. Cargo cults $^{53}$ were born as a way of explaining and making sense of why whites seemed to be so much better off materially than the local people. Whatever the impetus the result was inevitably disruption to an existing way of life. In neither Australia nor Vanuatu did the indigenous populations have a tradition of writing as it is known in the west. Customs are recorded through usage and oral accounts.

'Returning' to Custom is more than a symbolic strategy for many groups. In Australia the notion of incorporating aboriginal customary law into the municipal laws has been extensively examined..$^{54}$ Whilst in general there is little move to recognise customary law, in the context of native title it is the basis upon which decisions determining ownership will be made. ${ }^{55}$ Similarly in Vanuatu 'Kastom' has been legislated into the legal system and in land matters it is the determining factor. ${ }^{56}$

In Vanuatu the adoption of Custom is a conscious ideology initiated by those who pushed for independence. It is a clear example of a community wanting to give credence and value to its own creeds and codes of social control as a means of reestablishing a unique identity. ${ }^{57}$ In Australia, colonialism, which continues to exist, has governed the context in which customary rules are allowed to be determinative within the traditional environment because the colonial power (the Australian government) has made the rules about that. The Aboriginal people themselves have virtually no power to determine how effective their own 'laws' can be. If they follow their own laws they are sometimes breaking 'white-man's law.'

The great difficulty in the implementation of Custom as a matter of practice is the problem of deciding what Custom is. Where do genuine precepts come from after there has been so much disruption? Custom changes, even without traumatic interventions. Dynamic systems respond to new situations. Despite the common western misconception that customs are somehow 'written in stone', ${ }^{58}$ they are neither ageless nor immovable. Whilst communities understand that there has been a profound impact during the colonising years on their means of social organisation they nevertheless crave a returning to something genuine and wholly their own. This is as true for indigenous women as it is for the men.

\section{WHERE ARE THE WOMEN'S VOICES?}

In Melanesian communities the division of labour is generally drawn on gender lines. ${ }^{59}$ This is not uncommon in traditional indigenous societies. Only recently have we come to see that throughout the pre-colonial period there existed in traditions a body of knowledge that was exclusively female.

'Women's business' is also emerging as an ongoing vital tradition among Australian Aboriginals. Pat O'Shane refers to three specific anthropological re-examinations and notes: 
[A]ltogether, then it would appear that far from being 'abject pawns in the games of male political power' Aboriginal women enjoyed a greater degree of economic, social and political power than did women in Western society. ${ }^{60}$

Yet one needs to look very deeply into the literature generated by western academics and anthropologists to find any mention of aspects of traditional lore that might spring from and be fostered by women predominantly, or exclusively.

In 1955 Colin Simpson wrote a book of "vivid studies of Melanesia" called Islands of Men. ${ }^{62}$ It commences with an "Author's Note: Why Islands of Men" in which he writes:

Melanesia seems to me to be characteristically male, and Polynesia female... in the 'Black Islands' to the west [of Polynesia] the women are less attractive than their Polynesian sisters. The warrior male is, dramatically and even savagely, the figure dominant in our Melanesian image. (The emphasis is mine).

One could write a whole essay unpacking that snippet, but there is more. Later in the book Simpson relates a story told to him by one Tom Harrisson who had come to the New Hebrides as a biologist with the Oxford Expedition. Harrisson describes ridgetop Santo villages "where the menstruating women are kept in cages at one end and fed through the bars with bananas". ${ }^{63}$ Simpson further reports Harrisson as saying "[L]ife was good in those [communal] houses. In the night, if you were careful, you could get anywhere. In most parts one does not see enough of the ordinary life of the women. Here one saw more than enough". ${ }^{64}$

Simpson is described on the dust jacket as a "trained observer" but no other qualifications are revealed. He wrote three other books entitled respectively, Adam in Orche: Inside Aboriginal Australia, Adam with Arrows: Inside New Guinea and Adam in Plumes. One is left to wonder about Eve.

In 1965 P. Lawrence and M. J. Meggitt edited a book containing articles about Melanesian religions. ${ }^{65}$ In it R. B. Lane ${ }^{66}$ wrote a piece about the people of South Pentecost ${ }^{67} . \mathrm{He}^{68}$ describes a situation illustrating a decision making process:

In the evening around the cooking fire in the communal men's house where every event of the day is brought forth, re-created, and dissected for the edification and pleasure of the group, he presented his experiences... The discussion went on through most of the night... The ultimate consensus of opinion was that $\mathrm{W}$. had actually had an encounter with a spirit-being. ${ }^{69}$

He talks about analysis taking place in group discussions and notes that "individual conclusions are not necessarily disclosed in public". ${ }^{70}$ The analysis he describes takes place in the absence of the women who are presumably having similar conversations in their own communal house from which the writer is excluded. 'Public' presumably means the collective of men, women and children of the village. Perhaps women also decline to disclose their discussions in public. The notion that every event of the day is discussed by the men begs serious questions about what the women experience all day long. 
Later in the article we find a subheading, "Graded Society" ${ }^{71}$ This section runs for four pages. Having given three full paragraphs of explanation about the men's grading system, the fourth small paragraph states:

Associated with the men's graded society is a less elaborate women's graded society. There are three basic grades with subdivisions and each of the grades may be repeated at different times in different ways. The taking of these women's grades is sometimes linked with the achievements in the men's society by a woman's son or husband. ${ }^{72}$

So much for that, now let's get back to eight more paragraphs about the important stuff of men's grades. Even the scant material about the women's system is relevant only in so far as it arises from achievements of the woman's male kin.

This selectivity mechanism is frequently repeated and has been increasingly identified by feminist writers. ${ }^{73}$ Its effect is to rub out matters of interest and concern to indigenous women and thereby render the women completely devoid of any political voice for themselves. Deborah Bird Rose discusses this phenomenon of erasure ${ }^{74}$ in the context of Aboriginal native title land claims. Indigenous knowledge systems include boundaries of exclusion and silence across gender lines. She argues that colonisation has had the effect of importing western European notions of gender into the Australian consciousness and land claims are squeezed into that framework. Aboriginals must substantiate their links to their land by giving oral evidence. The process excludes women in two ways. The available bodies of learning have made men the central players and men's business the prime focus. Women's concerns are seen to be merely peripheral to those of men. This is the consequence of a white male anthropological construct such as the one described above. Further, the need for women to protect their traditions requires silence. If they speak their secrets to men they break their lores, if they do not their silence is interpreted as "absence of knowledge". ${ }^{75}$

Serious consequences of erasure arise when the learning and understanding accumulated in these texts is relied upon today by indigenous people themselves to help reconstruct their customs. Another factor is the disproportionate growth and development that might take place in the two gendered streams of custom and tradition following contact with whites. Women's business may not make dynamic strides to keep up with modernising influences. Equally the division of labour and power between the sexes is likely to widen.

Margaret Jolly has identified examples of both these phenomena. ${ }^{76}$ In her study about the relationship between men and women in food production in South Pentecost she notes the influences of colonialism. Among the traditional people (those less influenced by having been Christianised $)^{77}$ men's leaving home to work temporarily on other islands is a preferred strategy for raising cash. This pattern of migration has had the effect of increasing the work load for women while the men are away and reducing the power women have to influence what happens to the product of labour. 
The men exercise greater control over the cash and what it buys than they did over the food grown collectively.

Jolly identifies two other interesting spin-offs. Firstly, since the men tend to travel in groups:

They thus secure themselves against the depredations of European bosses, and the more ethereal ravages of alien sorcerers. This time together... [is] like an extended experience of the mal. ${ }^{78}$ Thus it tends to heighten male solidarity, vis-à-vis women. ${ }^{79}$

Possibly the same male bonding took place amongst young men from different traditional villages who were sent away to do their secondary schooling overseas in the pre-independence years. Several of these men returned to Vanuatu and established the various independence movements. This is a further illustration of how western influence can tip the balance between the traditional sex roles so that women's traditional role loses value.

Second, "[m]ales also monopolize contact with European ideas and values. They quite consciously inhibit the contact which women have with the outside world." 80 Through greater 'sophistication' in the ways of the west and with material goods (for example firearms) the men further exclude women from exercising power in the community.

The interweaving complexity of the influences that contact with western cultures has had on indigenous groups like the Australian Aboriginals and the ni-Vanuatu is too profound to describe in all its detail. What can be said is that it has had a major impact on those parts of traditional systems that are devised and operated by women. How does it impact on indigenous communities now? How does it affect the position of indigenous women struggling to establish their right to self-determination within their own communities?

\section{DEFINING THE MASCULINIST RHETORIC OF NOSTALGIA.}

Nostalgia is a sentimental longing or wistful affection for the past. It is a desire for a return to a period or place with happy personal associations. This is one of the theoretical underpinnings of the political project for re-establishing Custom. Why then 'rhetoric', with its negative connotation of insincerity? ${ }^{81}$ Is it not as Ati George Sokomanu past President of Vanuatu has written:

The political demand is to reconstitute, reclaim, revive and reinvent, because of what has been destroyed or lost under colonial rule. It is an urge simply to attain political power and freedom not only from colonial domination and oppression, but also from Christian ethics. It constitutes a process of santification (sic) of a new creation for a common cultural identity. ${ }^{82}$

This is passionate language that speaks of a common struggle for rebirth. But Sokomanu goes on to state that the "real past must be argued with proof, perhaps 
genealogically and ritually... for Pacific Islanders, their history is in the form of a story that is passed from the great-grandfather to grandfather to father to son" ${ }^{83}$ Here is proof that the 'proof' used to reconstitute, reclaim, revive and reinvent will be men's stories about men.

Women must be vigilant in analysing seemingly laudable propositions so as not to be swept up in the male rhetoric of Custom. When the Acting Chief Justice of Vanuatu (as he then was) stated in a judgment, ${ }^{84}$ "it is clear from the lessons of history that the price to be paid for failure to cherish and uphold the customs and traditions of Vanuatu, is a heavy one: the loss forever of a national identity and way of life" he is engaging in one form of rhetorical nostalgia. The price has been a heavy one; almost certainly heavier for women, ${ }^{85}$ but the loss was not of a national identity as that never existed in the first place. ${ }^{86}$

Indigenous men wittingly and unwittingly conspire in reducing the perceived importance of women's business for their own ends. ${ }^{87}$ Indigenous men may wish to exploit the position of women in the light of their own exploitation by colonisers and consequent feelings of alienation, and repress women as a means of overcoming their own 'castration's8 feelings at the hands of their colonial masters, ${ }^{89}$ but (whilst this process might be expected, accepted and understood) its outcome is the oppression of women.

The overwhelming male rhetoric of Custom is often a lie that can be used to foster greater gender power of men in the indigenous communities. At several levels men may use the impact of colonialism to reinterpret Custom to suit themselves. At its highest level, a whole stream of Custom has ceased to exist through a combination of anthropological inputs largely of the Simpson variety and great disturbances in and movement away from traditional life styles. This can lead to complete annihilation of women's business. Of course it has a substantial impact on the culture as a whole. In Vanuatu there has been surprisingly little academic study of Custom ${ }^{90}$ with substantial gaps in time between studies. Fairly isolated communities are selected for fieldwork but, inevitably, general conclusions are drawn and encompassing findings are made from these data. In the communities nearest to urban centres the de-Customising is often greatest because of the impact of western churches and missionaries and exposure to expatriate labour roles. There may be no collusion by indigenous men with the colonisers in the prime process but neither are the men unaware of the benefits they alone derive from these dislocations. It was the 'big-men', (selected by the colonisers usually) who got the privileges available from the dominant culture. ${ }^{91}$ Having thus gained standing, that power base has been developed to gain rank recognised in Custom. ${ }^{92}$

The second level operates because outsiders (anthropologists, settlers, historians, tourists, whoever) have misinterpreted the place of men and women in indigenous culture and have put everything into a western patriarchal framework. We shall never know what the traditional mode of living was for many Australian Aboriginal communities. Larissa Behrendt is an urban Aboriginal woman of the Eualeyai ${ }^{93}$ and she explains that her remarks about her culture are based on generalisations and what 
she has been told of her language group's customs and values. She maintains that there did not exist a concept of men being generally dominant to women, in her traditional culture..$^{94}$

Because the spirit of creation was a female energy, there is respect for women and nurturing is valued in our traditional community. We, as women, had and still have spiritual rituals, dances, songs and stories that are for women only. We are respectful of elders. We know that with age and experience come wisdom and powers. Women in our community are given as much respect as men. A female elder can be as influential in a community as a male elder. ${ }^{95}$

But she acknowledges that "[s]exist oppression by [black] men started when the white invaders arrived". ${ }^{96}$ We have already noted how women's grades in Vanuatu have been glossed over and substantially ignored in the western literature. In Vanuatu, pig-killing is a widespread ritual, significant for many purposes including cementing friendships, inaugurating chiefs and taking grades. One can still attend pig-killing ceremonies conducted by and for men. Ceremonies involving women being engaged in pig-killing are never discussed. Yet Margaret Rodman has documented women's pig killing rituals on East Aoba. ${ }^{97}$

These days in order to establish and maintain a political presence Aboriginal people are required to organise into committees and lobby groups. This mechanism has been picked up and developed by indigenous men. ${ }^{98}$ Invariably, one sees the same imbalance of gender representation in these bodies as one does with non-indigenous activities. Deborah Bird Rose ${ }^{99}$ notes the importance of the written record in Aboriginal claims and the fact that this record becomes a permanent structure for describing the 'truth' about ownership. The Land Councils (Aboriginal bodies) have a "tunnel vision approach... which asserts that as long as people get their land, it does not matter who gives evidence... gender equity appears to be classed as an optional extra... The idea is that people present their case, get their land, and get on with their lives". ${ }^{100}$ She notes the fallacy of this notion. In fact people do incorporate the elements utilised in the claim procedure into their lives. ${ }^{101}$ Thereafter, "[e]ven junior men... are treated as if they know more than the most senior women." ${ }^{102}$

Thirdly, the situation arises where women are denied a vehicle for their traditions to be recognised. In Helen Stacy's analysis of the Hindmarsh Island case ${ }^{103}$ she outlines how women of the Ngarrindjeri tribe, who were opposed to the construction of a bridge to the island for reasons that were based on secret women's business, were subject to allegations that their lore was a fabrication: ${ }^{104}$

Doug Milera, a senior Ngarrindjeri man and the husband of one of the women claiming to be a custodian of the secret women's business, claimed that the beliefs had been fabricated in an effort to stop the bridge. He subsequently withdrew his allegations of fabrication, saying that he had been drunk at the time of making the claim. ${ }^{105}$ 
Because he is a man his view was initially given greater credence in the public arena than the word of the women, and this doubtful credibility about this issue lingered despite his later discrediting of himself. ${ }^{106}$

On a fourth level, in the situation where an existing custom becomes substantially modified because of a change in circumstances, men again reinvent and thereby gain greater control over women. For example, in Vanuatu where custom owners of land or family members obliged to pay value would once have settled the obligation with mats (produced by women) or pigs (tended by women) the trend is now to operate a cash economy. The payment with money changes the nature of the mutual obligations significantly, because women generally have less access to cash and therefore relatively less power. Alternatively, other women's greater access to cash wealth can operate to increase traditional penalties. Waiwo $v$ Waiwo and Banga ${ }^{107}$ concerned a petition for divorce on the grounds of adultery also the plaintiff wife sought damages from the co-respondent. ${ }^{108}$ Coincidentally, all three parties came from the same area and were governed by the same Kastom. A decision had already been made by their chiefs that the co-respondent (who was a financially independent woman) should pay the plaintiff 10,000 vatu. ${ }^{109}$ They also ordered the respondent to pay the co-respondent's husband 20,000 vatu. The co-respondent argued that any further claim would amount to punitive damages. The Senior Magistrate ${ }^{110}$ held that damages should be awarded in accordance with customary law. He noted the seriousness with which adultery is regarded in Kastom and ruled "that there is a common basis throughout Vanuatu that adulterers must be customarily penalized... [thus] damages [for adultery] should be considered as punitive damages on the basis of custom". ${ }^{111} \mathrm{He}$ then ordered the payment of 100,000 vatu. ${ }^{112}$ Interestingly, he made no reference to the discussion about adultery in the document prepared by the Malvatumauri ${ }^{113}$ (the paramount council of chiefs) which would seem to have been a good source for the customary position on the matter. In any event that document offers no indication of the appropriate penalty. ${ }^{114}$ This case highlights brilliantly the difficulty of reconciling imported concepts with traditional ones. If damages for adultery were to be payable as a matter of custom (rather than as a surviving anachronism from English property law) then surely the most suitable assessors of the quantum of those damages would be the parties' own area chiefs and the principles for determining that quantum should also stem from custom.

Fifthly, where the power paradigm has become entirely patriarchal men become the sole arbiters of what custom was and so what it is to be. This level involves more direct gender oppression. At its most overt it is a bald assertion of gender dominance and the least subtle employment of the rhetoric of nostalgia. For example in Vanuatu a white female citizen was appointed as the first Ombudsman. ${ }^{115}$ Certain indigenous men in authority came under scrutiny and the Ombudsman published a number of reports outlining quite serious allegations of misconduct against senior politicians. One Member of Parliament ${ }^{116}$ stated publicly that he did not have to take any notice of the allegations because a woman issued them and they were therefore contrary to Kastom. Upon this rationale he did not feel obliged to address the question of the validity or otherwise, of the allegations. 
Finally there are circumstances where men simply tell lies about Custom. In land claims in Vanuatu this situation is not infrequent ${ }^{177}$ where competing male disputants will adduce evidence about apparent customary rules but all will neglect to explain the matrilineal aspects of their customary succession.

\section{CONCLUSION}

Dissecting the psyche and categorising personal planes of self in some perceived hierarchy is a western theoretical device. If western women have become discomforted by being analysed and analysing themselves in such splintered terms, how much more must that be true for indigenous women of colour whose cultural outlook is integrative rather than segregationalist.

Indigenous women of colour feel they are different from other people and want to be different in pursuing their individual identities and their unique collective identity. The collective identity involves a connection with the men of the group and the women do not want to deny this part of their identity. To be comfortable in that place given that as colonised people they experience 'spirit murder' in other places, they want to embrace the vitality of their Custom/Kastom/Country. Internally, solidarity requires consensus. That means that to be able to feel connected to each other within a customary framework, men and women need to agree upon the general principles that will govern them. Equally, externally the political agenda proscribes divisiveness. To strengthen the collective claim for the validity of custom indigenous men and women do not want to be seen as being at loggerheads.

Neither do women want to criticise traditional mores and customs because that may stimulate outsider scorn that Custom is primitive and uncivilised. The drive for a reinvigoration of Custom thereby potentially casts women into another form of schizophrenia because the loyalty to a customary ideology comes up against the masculinist interpretations that erase their gender perspective. Indigenous men know 'spirit murder' too. While indigenous men struggle to overcome the past they must not be allowed to redefine it so as to spirit murder their women anew. 


\section{ENDNOTES}

1 Huggins, J. 1998. Sister Girl. Queensland Australia: University of Queensland Press, p 120.

2 Pat O'Shane in Mitchell, S. 1984. Tall Poppies. Australia: Penguin Books, p 153.

3 One of the underpinnings of the western philosophical model as compared to less linear, less categorical systems, is a difference in concepts of 'time'. See, e.g., Herman, A. 1997. The Idea of Decline in Western History. New York: The Free Press, p 13.

4 As in the concept of the 'noble savage' being the idealised representative of primitive mankind of Romantic literature symbolising the innate goodness of humanity when free from the corrupting influence of civilisation. See too Rolls, M. 1998. Cultural Colonisation: Monica Furlong and the Quest for Fulfilment. The Australian Feminist Law Journal 11: 46-64.

5 Capitalised 'Custom' is used to denote the concept at its widest which encompasses traditions, norms, rites and practices, religious concepts and observances, rituals and art.

6 'Autonomy' here is meant in a somewhat restrictive sense, as a freedom from oppression rather than freedom from external control or influence.

7 Nelson, C./UN/ESCAP. 1999. Promoting CEDAW Through NGO Networks in the Pacific: Project Implementation Report.

8 Young, I. M. 1990. Justice and the Politics of Difference. Princeton: Princeton University Press, p 13.

9 Pettman, J. 1993. Gendered Knowledges: Aboriginal Women and the Politics of Feminism. Journal of Australian Studies 35:120-131.

10 See above, $\mathrm{n} 8$ at $\mathrm{p} 8$.

11 Hooks, B. Ain't I a Woman. 1981. USA: South End Press; Harris, A. 1994. Foreword: The Jurisprudence of Reconstruction. California Law Review 82:741-785; Williams, J. 1991. Dissolving the Sameness/Difference Debate: A Post-Modern Path Beyond Essentialism in Feminist and Critical Race Theory. Duke Law Journal 296-347.

12 See, for example, O'Shane, P. 1976. Is There any Relevance in the Women's Movement for Aboriginal Women? Refractory Girl 31-32 Huggins, J. 1998. Above, nl.

13 For an alternative view, see Haggis, J. 1990. Gendering Colonialism or Colonizing Gender? Recent Women's Studies Approaches to White Women and the History of British Colonialism. Women's Studies International Forum 13:105-115.

14 Mohanty, C. 1998. Under Western Eyes: Feminist Scholarship and Colonial Discourses. Feminist Review 30:64-81. She uses the term 'women of colour' interchangeably with 'Third World women'.

15 Huggins, J. 1998. Above, n8 at p 65.

16 Threlfall, M. 1996. Mapping the Women's Movement London: New Left Books at p 48; Behrendt, L. 1993. Aboriginal Women and the White Lies of the Feminist Movement: Implications for Aboriginal Women in Rights Discourse. The Australian Feminist Law Journal 1:27-51 at p 27.

17 See above, n 12 and n 16, Behrendt, L. 1993 at p 32: O'Shane, P 1976. Above, 12 and Behrendt, L. Above, n 16 at p 32: "Aboriginal women feel that to turn against Aboriginal men and start treating them as the enemy is divisive and denies the strong cultural and political ties between Aboriginal people of both sexes." 
18 Native Title Act (Cth) 1993 (Australia).

19 Constitution (Vanuatu) article 95(3): "Customary law shall continue to have effect as part of the law of the Republic of Vanuatu".

20 Bell, D. 1993. Daughters of the Dreaming. Sydney: Allen \& Unwin.

21 Dussias, A. 1999. Squaw Drudges, Farm Wives, and the Dann Sister's Last Stand: American Indian Women's Resistance to Domestication and the Denial of Their Property Rights. North Carolina Law Review 77:637-729.

22 Jolly, M. 1991. The politics of difference: feminism, colonialism and decolonisation in Vanuatu. In Bottomley, S. (ed.) Intersexions: Gender/Class/Culture/Ethnicity. Sydney: Allen \& Unwin, p 57.

23 See, for example. Speiser, F. 1990. Ethnology of Vanuatu: An early Twentieth Century Study. Bathurst, Australia: Crawford House Press; Berndt, R. \& Berndt, C. 1996. The World of the First Australians: Aboriginal Traditional Life Past and Present. Canberra: Aboriginal Studies Press.

24 The elements of this interesting debate now raging in feminist international law circles raise questions beyond the scope of this paper. A human rights perspective tends to be based on individual interests and a discussion about Custom requires an examination of collective interests. But see Howe, A. 1994. White Western Feminism Meets International Law: Challenges/Complicity, Erasures/Encounters. The Australian Feminist Law Journal 4: 63-91.

25 The plight of the women in Afghanistan subject to the Taliban is an obvious example.

26 Young, I.M. 1990. Above, n 8 at 9.

27 The difficulties in reconciling customs and culture with eliminating discrimination against women is highlighted in countries like Vanuatu that have acceded to CEDAW. See above, $\mathrm{n} 7$.

28 Gale, F. (ed.) 1974. Woman's Role in Aboriginal Society. Canberra: Australian Institute of Aboriginal Studies, p 1.

29 Bell, D. 1993. Above, n 20 at p 3.

30 Huggins, J. 1998. Above, n 1 at p 65: “Our men, are starting to get a bit agitated with seeing Black women in this country gravitating towards feminism rather than back to the Black environment, the Black community if you will. The whole problem of where one is disloyal to their people or appears to be disloyal to their people is something that I, certainly as a Black woman, have had to grapple with".

31 Huggins, J. 1998. Above, n 1 at p 65

32 Huggins, J. 1998. Above, n 1 at p 103

33 Watson, I. 1998. Power of the Muldarbi, The Road to its Demise. The Australian Feminist Law Journal 11: 28-45 at p 38.

34 See, for example, Draft Declaration on the Rights of Indigenous Peoples United Nations Doc E/CN.4/SUB.2/1994/2/Add. 1.

35 Behrendt, L. 1994. Aboriginal Urban Identity: Preserving the Spirit, Protecting the Traditional in Non-Traditional Settings. The Australian Feminist Law Journal 4: 55-61, p 61.

36 Williams, S. 1991. Above n 11. 
37 Williams, P. 1987. Spirit-Murdering the Messenger: The Discourse of Fingerpointing as the Law's Response to Racism. University of Miami Law Review 42: 127-347.

38 Strethlow, T. J. H. 1986. Submission 33. Australian Law Reform Commission Report 31: The Recognition of Aboriginal Customary Laws.

39 Silko, L. M. 1996. Yellow Woman and a Beauty of the Spirit: Essays on Native American Life Today. New York: Simon \& Schuster, p 200.

40 Brown, K. 1997. Customary Law in the Pacific - An Endangered Species. Journal of South Pacific Law, article 2 of Vol. 3.

(http://www.vanuatu.usp.ac.fj/journal_splaw/articles/Brownl.htm Accessed 19/9/02).

41 Melanesia is usually taken to include the island of New Guinea and its lesser islands, Solomon Islands, Vanuatu, New Caledonia and Fiji Islands.

42 Brown, K. 1997. Above, n 40.

43 Note that it is estimated that Vanuatu has 108 different languages with each language community being associated with different elements of custom and culture. See Sokomanu, A. G. 1992. Government in Vanuatu: The Place of Culture and Tradition. In Crocombe, R. et al (eds.) Culture and Democracy in the South Pacific. Suva: Institute of Pacific Studies, p 52.

44 Sokomanu, A.G. 1992. Above, n 43.

45 Sokomanu, A.G. 1992. Above, n 43 at p 19. The term comes from New Guinea tok pisin. In the Bislama of Vanuatu, the term is "fasin" meaning "fashion, method, manner or way”. See Crowley, T. 1995. A New Bislama Dictionary. Suva: Institute of Pacific Studies, p 72 .

46 Sokomanu, A.G. 1992. Above, n 43 at p 19.

47 Hobbles Danayarri quoted in Rose, D.B. 1984. The Saga of Captain Cook: Morality in Aboriginal and European Law. Australian Aboriginal Studies 2: 24-42 at p 31.

48 See Bottomley, S. \& Parker, S. 1997. Law in Context (2nd ed.). Canberra: The Federation Press, chapter 10.

49 See, for example, Rose, D. B. 1996. Land Rights and Deep Colonising: The Erasure of Women. Aboriginal Law Bulletin 3: 6-13.

50 See, for example, Behrendt, L. 1993. Above, n 16; and Behrendt, L. 1994. Above, n 35.

51 See Shineberg, D. 1967. They Came For Sandalwood. Carlton, Victoria: Melbourne University Press.

52 See Docker, E. W. 1981. The Blackbirders: A Brutal Story of the Kanaka Slave-trade. Australia: Angus \& Robertson.

53 See, for example, Worsley, P. 1974. The Trumpet Shall Sound: A Study of 'Cargo' Cults in Melanesia. New York: Schocken Books.

54 See Australian Law Reform Commission. 1986. Report 31: The Recognition of Aboriginal Customary Laws.

55 Native Title Act 1993 (Cth).

56 Constitution (Vanuatu) article 74. In the last two years, work has been done towards establishing a customary system of determining issues of land ownership throughout Vanuatu. 
57 In practice the implementation of customary law has been limited. See, for example, Brown, K. 1997. Above, n 40.

58 See Bottomley, S \& Parker, S. 1997. Above, n 48.

59 See, for example, Speiser, F. 1990. Above, n 23.

60 See O'Shane, P. 1976. Above, n 12, at p 32.

61 This is a quote from the dust jacket summary.

62 Simpson, C. 1955. Islands of Men: Inside Melanesia. Sydney: Angus \& Robertson.

63 See Simpson, C. 1955. Above, n 62 at p 118.

64 See Simpson, C. 1955. Above, n 62 at p 118. Harrisson himself published a book entitled Savage Civilisation.

65 Lawrence, P. \& Meggitt, M.J. (eds.) 1965. Gods, Ghosts and Men in Melanesia: Some Religions of Australian New Guinea and the New Hebrides. Melbourne: Oxford University Press.

66 Lane R.B. 1965. The Melanesians of South Pentecost, New Hebrides. In Lawrence, P. \& Meggitt, M.J. (eds.) Gods, Ghosts and Men in Melanesia: Some Religions of Australian New Guinea and the New Hebrides. Melbourne: Oxford University Press at p 250.

67 Pentecost is an island of Vanuatu.

68 Presumably the author is male. None of the authors are identified anywhere with their first names. R.B. Lane notes that he collected the data for the article in field trips funded by a Fulbright grant and the Carnegie Corporation of New York. Margaret Jolly, in a later work, notes that American anthropologists Bob and Barbara Lane did field trips in 1953-4 and 1957-8. See Jolly M. 1981. People and Their Products in South Pentecost. In Allen, M. (ed.) Vanuatu: Politics, Economics and Ritual in Island Melanesia. Sydney: Academic Press, at p 290.

69 Lane, R.B. 1965. Above, n 66 at p 252.

70 Lane, R.B. 1965. Above, n 66 at p 252.

71 Lane, R.B. 1965. Above, n 66 at p 270.

72 Lane, R.B. 1965. Above, n 66 at p 271.

73 See, for example, above, n 12, at p 31 and above, n 16, Behrendt, L. 1993 at p 29.

74 Rose, D. B. 1996. Above, n 49.

75 See above, n 74 .

76 Jolly, M. 1981. Above, n 68, at p 269. Interestingly, Jolly is studying the same region as Lane, the South Pentecost area.

77 Jolly, M. 1981. Above, n 68, at p 289. The people of Bunlap and Pohurur have retained their traditions and largely rejected christianising.

78 The mal is literally the 'men's house' but the concept encompasses 'men's business'.

79 Jolly, M. 1981. Above, n 68, at p 288.

80 Jolly, M. 1981. Above, n 68, at p 289. (My emphasis.)

81 Note the definition in The New Oxford Dictionary of English "language designed to have a persuasive or impressive effect on its audience but which is often regarded as lacking in sincerity or meaningful content". For an interesting discussion about the role of language in the law and two sides of rhetoric see Meehan, M. 1994. An Anatomy of Australian Law or The Human Element in Legal Argument. In The Happy Couple: Law and Literature. Sydney: The Federation Press, at p 376. 
82 Sokomanu, A.G. 1992. Above n 43 at p 52.

83 Sokomanu, A.G. 1992. Above n 43 at p 53.

84 Peter Salemalo v Paul Ren Tari and the Electoral Commission, Unreported, Supreme Court of the Republic of Vanuatu, Election Petition No. 30 of 98 28th August, 1998 (http://www.vanuatu.usp.ac.fj/paclawmat/Vanuatu_cases/Volume_R-Z/Salemalo_v_Tari .html Accessed 19/9/02).

85 See, for example, Behrendt, L. 1993. Above, n 16 at p 28: "The culture and spirituality of Aboriginal women is being destroyed at a faster rate than that of Aboriginal men."

86 Vanuatu's pre-contact history is one of isolated communities existing throughout the islands each having little contact with the others. Even today ni-Vanuatu identify themselves first by the village or island community from which they come. The creation of Vanuatu as a nation state is a post-colonial contrivance.

87 I am indebted to Prof. Jean Zorn for her insightful comments about these issues.

88 This seems an appropriate metaphor for indigenous men's own feelings of powerlessness in the face of white domination and it may help to explain the apparent attraction of an extreme macho image to indigenous men that can be observed. Having said that one must also be very mindful of the dangers in stereotyping their behaviour.

89 In Vanuatu today there are still some elderly ni-Vanuatu men who refer to white men as 'masta' more than twenty years after independence.

90 Brown, K. 1997. Above, n 40 at p 1 where he notes the paucity of reliable and detailed anthropological information.

91 Van Trease, H. 1987. The Politics of Land In Vamuatu. Suva: Institute of Pacific Studies. He cites the case of Peter Milne, missionary on Nguna who sought to suppress the matrilineal tradition because it appeared to him to be contrary to the Scriptures (p 9).

92 Kalsakau, G. 1978. History of the Three Flags. Vanuatu: I.P.V, in which he outlines the history of his own powerful chiefly family.

93 Behrendt, L. 1993. Above, n 16 and Behrendt, L. 1994. No One Can Own the Land. Australian Journal of Human Rights 1(1): 43-56.

94 Behrendt, L. 1994. Above, n 93, at p 55.

95 Behrendt, L. 1994. Above, n 93, at p 56.

96 Behrendt, L. 1993. Above, n 16, at p 33.

97 Rodman, M. 1981. A Boundary and a Bridge: Women's Pig Killing as a Border-Crossing Between Spheres of Exchange in East Aoba. In Allen, M. (ed.) Vanuatu: Politics, Economics and Ritual in Island Melanesia Academic Press: Sydney. Either the practice has ceased or it is not generally referred to, in either case its erasure is instructive.

98 Berndt, R. \& Berndt, C. 1996. Above, n 23 at p 542: "Many Aboriginal communities now have their own councils of management, with responsibility for controlling socioeconomic projects."

99 Rose, D.B. 1996. Above, n 49.

100 Rose, D.B. 1996. Above, n 49 at $\mathrm{p} 9$.

101 Rose, D.B. 1996. Above, n 49 at p 9.

102 Rose, D.B. 1996. Above, n 49 at p 9. 
103 Stacy, H. 1996. Lacan's Split Subjects: Raced and Gendered Transformations. The Legal Studies Forum XX(3):277-293.

104 Stacey, H. 1996. Above, n 103 at p 283; Rose, D.B. 1996. Above, n 49.

105 Stacey, H. 1996. Above, n 103 at p 284. A group of women from the same community also disputed the existence of the special knowledge but that does not affect the argument that women's business is often systematically belittled or denied by those having no knowledge of it.

106 As Stacy points out, his later loss of credibility is explained in racist terms as a component of his black unreliability.

107 Unreported, Senior Magistrate's Court of the Republic of Vanuatu, civil case No. 324 of 1995 28th February, 1996 (http://www.vanuatu.usp.ac.fj/paclawmat/ Vanuatu_cases/Volume_R-Z/Waiwo_v_Waiwo.html Accessed 19/9/02).

108 Damages for adultery are provided for in the Matrimonial Causes Act [Cap 192] (Vanuatu) s 17.

109 The equivalent of approximately 120 AUD.

110 Mr. Lunabek has since been appointed Chief Justice.

111 See above, n 107 at p 9.

112 This case went to appeal. See Banga $v$ Waiwo, Unreported, Supreme Court of the Republic of Vanuatu (appellate jurisdiction), Appeal Case No. 1 of 1996 17th June, 1996

(http://www.vanuatu.usp.ac.fj/paclawmat/Vanuatu_cases/Volume_A-F/Banga_v_Waiwo .html Accessed 19/9/02).

113 Custom Policy of the Malvatumauri issued by the (Vanuatu) National Council of Custom Chiefs.

114 See above, n 113, article 24 .

115 This is a constitutional position provided for in Part II Article 61 of the Constitution of Vanuatu.

116 Barak Sope. Mr Sope held the position of Minister for Finance and has also been Prime Minister in Vanuatu.

117 See, for example, the discussion in John Noel v Obed Toto, Unreported, Supreme Court of the Republic of Vanuatu, Civil Case No 18 of 1994 19th April 1995 (http://www.vanuatu.usp.ac.fj/paclawmat/Vanuatu_cases/Volume_G-N/Noel_v_Toto.html Accessed 19/9/02). 